\title{
Ticari Açıklığın Siyasal İktisadı ve Yolsuzluk Üzerindeki Etkileri
}

\section{The Political Economics of Trade Openness and Its Impacts on Corruption}

\author{
Orhan CENGIZ1 (i)
}

\section{ÖZ}

Gelişmekte olan ülkelerin dışa açılma ile beraber maruz kaldıkları çeşitli riskler söz konusudur. Küresel ekonomiyle daha fazla bütünleşmenin ve ticari engellerin kaldırılmasının, kaynak dağıımında verimliliği sağlaması ve refahı artırması beklenirken, bu durum birçok ülkede gerçekleşmemektedir. Gelişmekte olan ülkeler için ticari serbestleşme arayışında ticari engellerin kaldırılması, rant arama faaliyetlerine yol açabileceğinden ticari açıklığın ekonomik sonuçlarına ilave olarak, politik ve kurumsal yapılar üzerindeki etkisi de önemlidir. Bu çalışma, Türkiye ve seçilmiş MENA ülkelerinde 1996-2018 dönemi verileriyle Genişletilmiş Ortalama Grup (AMG) yöntemi kullanılarak dışa açıklığın yolsuzluk üzerindeki etkisini analiz etmektedir. Sonuçlar, ticari açıklığın yolsuzluğun kontrolünü azalttığını; buna karşılık ekonomik büyüme, hukukun üstünlüğü ve kamu harcamalarının ise yolsuzluğun kontrolünü artırdığını göstermektedir. Bunun yanında Dumitrescu-Hurlin (2012) nedensellik testi bulguları, değişkenler arasında farklı ilişkinin varlığını ortaya koymaktadır.

Anahtar kelimeler: Ticari açıklık, Yolsuzluk, Küreselleşme JEL Sınıflaması: F19, F61, F68

\section{ABSTRACT}

Developing countries are exposed to various risks as they open their economies. While becoming more integrated with the global economy and removing trade barriers is expected to improve efficiency in resource allocation and increase welfare, in many countries this does not occur. In addition to the economic consequences of trade openness, its impact on political and institutional structures is significant for developing countries as removing trade barriers in pursuit of trade liberalization can lead to rent-seeking activities. This study investigates the impact of trade openness on corruption using the Augmented Mean Group (AMG) method with data from Turkey and selected MENA countries over the period 1996-2018. The results show that trade openness reduces control of corruption, while economic growth, the rule of law, and public expenditures increase control of corruption.

${ }^{1}$ Öğr. Gör. Dr., Çukurova Üniversitesi, Pozantı Meslek Yüksek Okulu, Muhasebe ve Vergi Bölümü, Adana, Türkiye

ORCID: O.C. 0000-0002-1883-4754

\author{
Sorumlu yazar/Corresponding author: \\ Orhan CENGiZ, \\ Çukurova Üniversitesi, Pozantı MYO, Muhasebe \\ ve Vergi Bölümü, Çukurova Üniversitesi \\ Pozantı Meslek Yüksekokulu, Adana, Türkiye \\ E-posta/E-mail: ocengiz@cu.edu.tr
}

Başvuru/Submitted: 01.10.2021 Revizyon Talebi/Revision Requested: 01.11.2021

Son Revizyon/Last Revision Received: 22.11.2021

Kabul/Accepted: 22.11.2021

Atıf/Citation: Cengiz, O. (2021). Ticari açıklı̆ı̆ın siyasal iktisadı ve yolsuzluk üzerindeki etkileri. istanbul iktisat Dergisi - Istanbul Journal of Economics, 71(2), 499-525. https://doi.org/10.26650/ISTJECON2021-1003148 
In addition, Dumitrescu-Hurlin's (2012) causality test findings reveal the existence of different linkages between variables.
Keywords: Trade openness, Corruption, Globalization

JEL Classification: F19, F61, F68

\section{EXTENDED ABSTRACT}

Globalization is a central concept that characterizes today's economies. Globalization is extensive in scope, encompassing the cross-border movement of goods, capital, and individuals and thereby affecting almost all disciplines. The impacts of globalization are not limited to economics but extend to political, social, and cultural changes. During the period dominated by Keynesian economics, from World War II to the 1970s, the state's role in the economy expanded and the view that demand-oriented government policies would increase welfare became widespread. After the 1970s, many countries around the world took steps toward radical changes in economics and politics. The idea that the welfare state, as identified in Keynesian economics, leads to inefficiency, wasted resources, and corruption in the public sector, started to take hold on political-economic grounds.

The new world order that began in the 1970s focuses on a structure that differs from previous periods, reducing the role of the state in the economy, increasing integration across countries, and removing economic and trade barriers. International organizations under the control of developed countries, such as the International Monetary Fund and the World Bank, have tried to persuade underdeveloped and developing nations to benefit from globalization by opening up their economies. The Washington Consensus, proposed by John Williamson (1990), is a manifesto that specifies the reforms developing countries should implement in order to adapt to globalization. The impact of integrating with international markets on individual countries is not only economic; it also affects corruption, which is closely related to political decision-making and corporate governance. The theoretical literature in this field focuses primarily on the impacts of corruption on trade openness. However, trade openness itself influences corruption through various mechanisms. Optimistic views argue that 
trade openness reduces corruption by reducing monopolistic rents and the motivation to seek bribes. In contrast, those who argue that trade openness increases corruption state that the marginal utility of bribery for customs officers increases with openness, the control mechanism of commercial activities weakens, and there is an increased need for funds due to politicians' concerns about being re-elected that leads to a rise in rent-seeking activities.

Based on this framework, this study analyzes the impact of trade openness on corruption for a panel group consisting of Turkey and the MENA countries, Algeria, Bahrain, Egypt, Iran, Israel, Jordan, Kuwait, Lebanon, Malta, Morocco, Oman, Qatar, Saudi Arabia, and Tunisia, using data spanning the period from 1996 to 2018. The dependent variable is a control of corruption index, and the share of total exports and imports of a country's Gross Domestic Product (GDP) is used as an indicator of trade openness. Other explanatory variables include a rule of law index, real GDP per capita, and public expenditures. In the first stage of the empirical analysis, the cross-section dependence test, homogeneity test, and unit root test are performed. The Augmented Mean Group (AMG) method developed by Eberhardt and Bond (2009) is used to reveal a long-term relationship between the variables. After determining this long-term relationship, Dumitrescu-Hurlin's (2012) causality method is used to investigate the causality linkage between the variables. According to the AMG results, trade openness negatively affects the control of corruption in the panel countries. In terms of economic rhetoric, corruption increases with trade openness. In addition, the impact of other explanatory variables on corruption control is positive. Accordingly, we find that economic growth, the rule of law, and the increase in public expenditures reduce corruption by increasing the extent to which corruption is controlled.

The causality test performed after the parameter estimation reveals different findings. We show there are bidirectional causality linkages between control of corruption and economic growth, control of corruption and trade openness, trade openness and economic growth, the rule of law and economic growth, and public expenditures and the rule of law. In addition, one-way causality relationships are found from public expenditures to control of corruption, 
economic growth, and trade openness, and from trade openness and to the rule of law. Our findings are consistent with the pessimistic view that states trade openness increases corruption. The results offer various suggestions for policymakers in MENA countries and Turkey. When pursuing integration with the global economy, policymakers should develop policies to strengthen the rule of law, increase accountability and transparency, ensure political stability, improve regulatory quality, and make the public sector more effective to reduce the negative impact of globalization on corruption within the country. These countries should also implement policies that will improve institutional quality when integrating into the global economy. Therefore, beyond quantitative growth, qualitative development of the public sector becomes more critical. 


\section{Giriş}

Günümüz ekonomilerinde dışa açıklığın yarattığı etkiler çok geniş kapsamlıdır. David Ricardo'nun karşılaştırmalı üstünlükler modeline dayanan uluslararası işbölümünün, serbest ve rekabetçi bir piyasa ekonomisinin geçerli olduğu dünya ekonomisinde birincil ürünler sektöründe azalan verimler yasasının ve imalat sektöründe artan getiri yasasının geçerli olması nedeniyle birincil ürünler üreten ülkelerde dış ticaret hadlerinde iyileşmeye yol açacağı savunulmaktadır. Serbest ticaretle birlikte bu ülkelerin, uluslararası alanda yaratılan fırsatlardan yararlanma imkânı elde edeceği öngörülmüştür (Sarkar, 2008, s. 764). Buna karşıllk Raúl Prebisch öncülüğünde gelişen yapısalcı yaklaşımlar, merkez ve çevre ülkeler arasındaki dualistik üretim yapısı nedeniyle dış ticaretin çevre ülkelerin aleyhine işlediğini savunmaktadır (Saad-Filho, 2005, s. 132). Buna göre çevre ülkeler, genellikle teknolojiyi merkez ülkelerden ithal eden ve birincil ürün ihracatına dayanan ekonomik yapıya sahiptir. İhracat yapılan birincil sektör ile geçim sektörü arasındaki verimlilik farkı nedeniyle dualistik yapı kendisini daha fazla göstermektedir. Kapitalist merkez ülkeler, emek arzı bolluğuna sahip ülkelere üretimlerini kaydırarak çevre ülkelerde faaliyetlerine devam etmektedir. Emek bolluğunun çevre ülkelerde ücretlerin düşmesine yol açması ve dış ticaret hadlerinin bozulması nedeniyle ihracat sektöründeki verimlilik, merkez ülkelere kaymaya başlamaktadır. Bu nedenle yapısalcı yaklaşım, dış ticaretin merkez ve çevre ülkeler arasındaki asimetrik yapıyı giderek derinleştirdiğini savunmaktadır (Kay, 2011, s. 29).

Bu çerçevede ticari açıklığın ekonomik faaliyetleri ne ölçüde etkileyip etkilemediği konusunda teorik tartışmalar uzun süreden beri devam etmekle birlikte, baskın görüş dışa açıklığın kaynak dağııımında etkinliği sağlayarak uzun dönemli büyümeyi artırdığı yönündedir. Dolayısıyla teorik literatür, dışa açıklığın ekonomik büyümeyi etkilediği mekanizmaları öne çıkarmaktadır (Zakaria, 2009). İktisadi modellerde ticari açıkıkla ekonomik büyüme arasındaki ampirik bulgular farklılık göstermektedir. Bazı çalışmalar (O'Rourke, 2000; Irwin, 2002), ticari açıklık ile ekonomik büyüme arasında negatif ilişki bulurken; bazıları ise pozitif bir ilişki elde etmiştir (Barro, 1991; Sachs ve Warner, 1995; Awokuse, 2008; Tahir ve Azid, 2015; Musila ve Yiheyis, 2015). 
Ticari açıklıkta yaşanan artış sadece ekonomik büyüme, kaynak verimliliği veya refah artışı açısından sonuçlar yaratmamaktadır. Özellikle politik-ekonomi bağlamında ele alındığında ticari açıklığın ilişkili olduğu alanlardan birisi de yolsuzluktur. Küreselleşmenin neden olduğu rekabet baskısı bir taraftan ülkeleri kurumsal yönetişimi güçlendirmeye yönlendirirken, diğer taraftan ticari açıklıkla rant elde eden gruplar ortaya çıkmaktadır.

Dünya ekonomisinin giderek birbirine entegre olması, politik kaygılar açısından dışa açıklık ile yolsuzluk arasındaki ilişkiyi daha önemli kılmaktadır. Bu alanda hâkim olan görüş, ticari açıklı̆ın ülkeleri daha fazla rekabete zorladığı için tekelci rantları azaltarak, rüşvet faaliyetlerini ve yolsuzluğu azaltacağı yönündedir. Diğer taraftan ticari açıklık ile birlikte daha fazla mal ve hizmetin tüketicilerin kullanımına sunulması, tüketicilerin gelirinin marjinal faydasını artırmakta; fakat aynı zamanda yolsuzluk eğilimindeki kişiler açısından rüşvetin marjinal faydasını artırarak, yolsuzluğu teşvik etmektedir. Çeşitli mal hizmetlerin tedarikinde dışa bağımlı gelişmekte olan ülkelerde (GOÜ) ticari açıklık, yozlaşma eğilimini güçlendirmektedir (Baksi, Bose ve Pandey, 2009, s. 214-215). Wei (2001), coğrafi özellikleri ve büyüklüğü nedeniyle doğal olarak dışa açık olan ülkelerin, yolsuzluğun azaltılmasını sağlayacak kurumsal yönetişim altyapısını güçlendirme eğiliminde olduğunu savunmaktadır. Güçlü kurumlar inşa etmeye ayrılacak kaynaklar, içsel olması yanında marjinal maliyet ve marjinal fayda ilkesine göre belirlendiğinden, dışa açı ülkelerin kurumsal kaliteyi iyileştirmeleri en optimal durumdur. Knack ve Azfar (2003), Wei'nin (2001) temellendirmesine karşı çıkmakta ve dışa açık ülkelerde gümrük memurlarının elde edebileceği rant fırsatlarının artacağı hususuna vurgu yapmaktadır. Dolayısıyla daha fazla ticari açıklık, yolsuzluğu artıracak faaliyetleri teşvik edebilmektedir. Buna ilave olarak, yozlaşmış bürokratların ithalatçılardan aldıkları rüşvetler, bir nevi vergi işlevi haline gelerek ticareti de olumsuz etkilemektedir (Knack ve Azfar, 2003, s. 2-3). Teorik ve ampirik literatür, ticari açıklık ile yolsuzluk arasında farkı sonuçlar ortaya koymaktadır.

Bu çalışmada Dünya Bankası sınıflandırmasına göre Orta Doğu ve Kuzey Afrika (Middle East and North Afrika-MENA) ülkeleri kategorisinde olan Cezayir, Bahreyn, Mısır, İran, İsrail, Ürdün, Kuveyt, Lübnan, Malta, Fas, Umman, Katar, Suudi Arabistan ve Tunus'a ilave olarak Türkiye'den oluşan panel grubu için 1996-2018 
dönemi verileri kullanılarak ticari açıklık ile yolsuzluk arasındaki ilişki incelenmiştir. Çalışma altı bölüm olarak kurgulanmıştır. Konunun öneminin açıklandığı giriş bölümünden sonraki ikinci bölümde, ticari açıklık ile yolsuzluk arasındaki ilişkinin kuramsal boyutu ele alınmıştır. Üçüncü bölümde, ilgili literatürde yapılan çalışmaların özeti sunulmaktadır. Dördüncü bölümde, ampirik analizde kullanılan veriler ve uygulanan yöntem beşinci bölümde, analiz sonucunda elde edilen bulgular ortaya konulmuştur. Son bölümde ise ulaşılan bulgular çerçevesinde politika önerileri tartışılmaktadır.

\section{Ticari Açılık ve Yolsuzluk: Kuramsal Boyut}

Ticari açıklık küreselleşmenin önemli bileşenlerinden birisini oluşturmaktadır (Gygli, Haelg, Potrafke ve Sturm, 2019). Neoliberal küreselleşmenin bir parçası olarak ticaretin önündeki engellerin kaldırılmasıyla ekonomik büyüme ve refah artışııın sağlanacağı görüşü ana akım yaklaşımların temelini oluşturmaktadır (Deraniyagala, 2007, s. 169). Neoliberalizm ekseninde 1970'lerden başlayarak günümüze kadar olan süreçte, küresel ticaretin önündeki engeller önemli derecede azaltılmıştır.

Şekil 1. Gelir Gruplarına Göre Tarife Oranları, 1988-2017

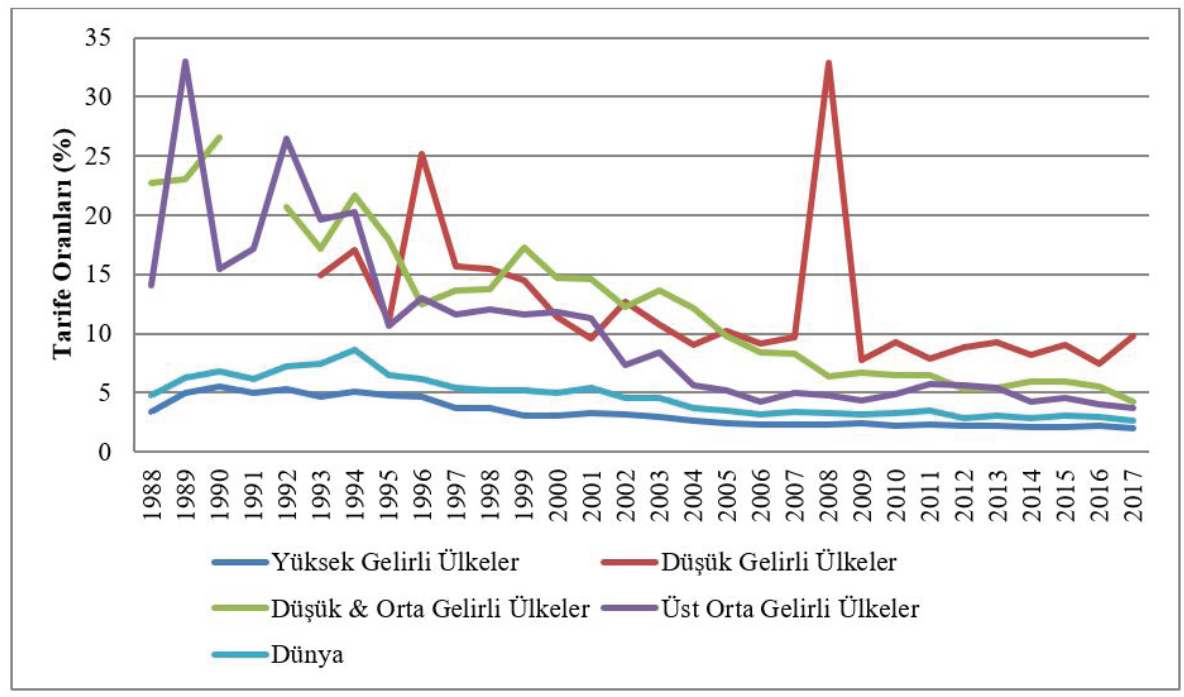

Kaynak: World Bank, 2021. 
Ticari açıklığı etkileyen unsurların en başında ticari engeller gelmektedir. Bunlar arasında tarife oranları en fazla kullanılan araçlardır. Gelir gruplarına göre tarife oranlarının gösterildiği Şekil 1 incelendiğinde tüm gelir gruplarında ve dünyada ortalama olarak tarifelerin azaldığı görülmektedir. Tarife oranları dünya genelinde 1988'de \%4.8 iken 2017 yılında \%2.6'ya düşmüştür. En düşük tarife oranlarının yüksek gelirli ülkelerde olduğu görülmektedir. Buna karşllık tarife oranlarının en yüksek olduğu gelir grubu, düşük gelirli ülkelerdir. Bir bütün olarak ele alındığında tarife oranlarının ticari açıklığı teşvik edecek yapıda olduğu ifade edilebilir.

Şekil 2. Ticari Açıklık Oranı, 1970-2019

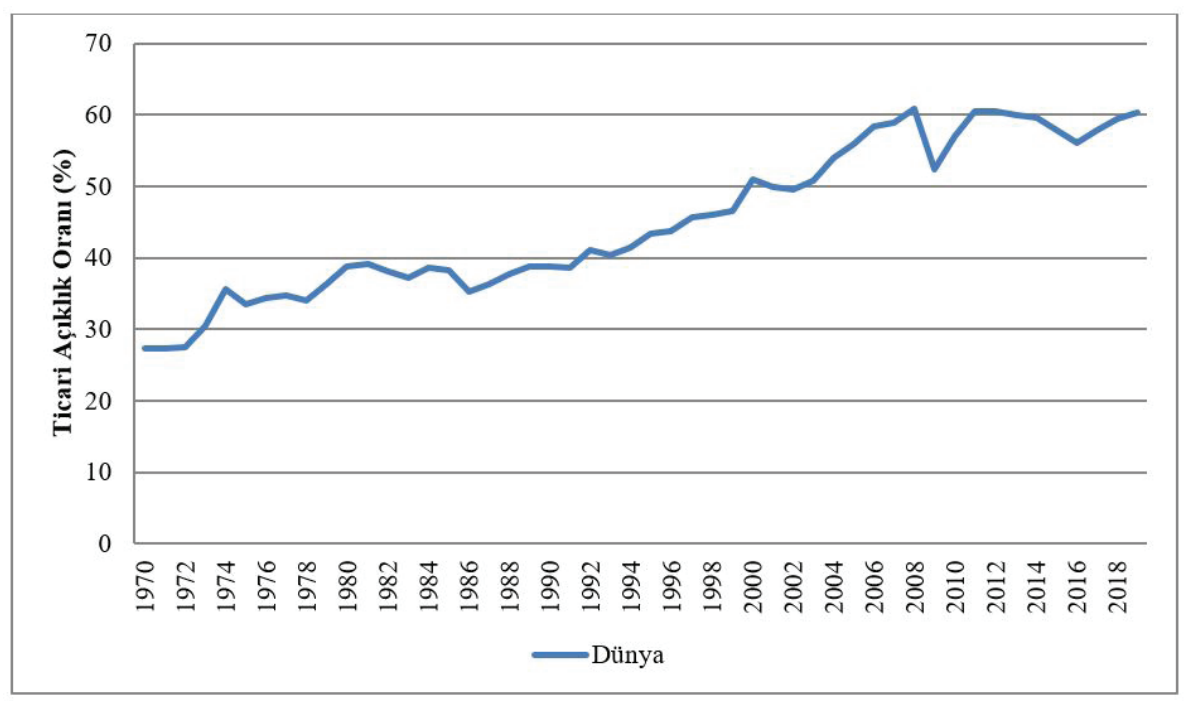

Kaynak: World Bank, 2021.

Tarife oranlarıyla ilişkili olarak ihracat ve ithalatın GSYIH içerisindeki payını (\%) ifade eden ticari açıklık oranı, Şekil 2'de gösterilmektedir. 1970'lerde \%27.3 seviyesinde olan ticari açıklık oranı, yaklaşık son 50 yıllık dönemde önemli bir ivme kazanarak \%60.3'e yükselmiştir. 2008 küresel finans krizinin etkisiyle belirli ölçüde gerileme görülse de daha sonraki dönemde yeniden artmaya başlamıştır.

Ticari açıklık ile yolsuzluk arasındaki ilişkinin yönüne ilişkin farklı görüşler söz konusudur. Birinci yaklaşım, yolsuzluğun dışa açıklık üzerindeki etkisine odaklanmaktadır. Buna göre rekabetçi olmayan ihale düzenlemeleri, seçici 
vergilendirme sistemi, rüşvet ve yapay olarak yaratılan tekelleşme eğilimleri, ihracat ve ithalat faaliyetlerini azaltarak dışa açıklığı olumsuz etkilemektedir. Dolayısıyla bu bakış açısına göre, ticari açıklığın artması için yolsuzluğun azaltılması gerekmektedir (Zakaria, 2009, s. 1-2). Bunun yanında ikinci yaklaşım, ticari açıklığın yolsuzluk üzerindeki etkisini ele almaktadır. Krueger'e (1974) göre ithalata yönelik kotalar konulduğunda ve ithalat kısıtlandığında, ithalat lisansları önemli hâle gelmektedir. İthalat lisansının kaynak dağılımı üzerindeki etkisi, bunu alanlara göre değişmektedir. Daha da önemlisi, kotalar ve diğer ithalat kısıtlamaları tarifelerin aksine, daha fazla tekel gücü yaratmaktadır. Ortaya çıkan bu rantın elde edilmesine yönelik rekabet, özel ve sosyal maliyetleri farklılaştırmaktadır. Piyasa sisteminin serbestçe işlediği ekonomide ekonomik faaliyetlere yönelik müdahaleler, bazı durumlarda yasal rantlara yol açarken bazı durumlarda yolsuzluk, rüşvet ve karaborsa gibi yasal olmayan biçimlere bürünmektedir.

Ticari açıklığı önündeki engellerin kaldırılmasının yolsuzluk üzerindeki negatif etkisi, genel kabul gören yaklaşımdır. Buna karşılık, ticaretin serbestleşmesinin yolsuzluk üzerindeki etkisinin pozitif olduğunu ortaya koyan yaklaşımlar da söz konusudur. Majeed'e (2014, s. 763) göre ticaretin serbestleştirilmesi, yeni mal ve hizmetlerin ithalatını artırmaktadır. İthalatın artmasıyla tüketicilerin gelirinin marjinal faydasını artırmaktadır. Bu etki, özellikle çok çeşitli ürün kompozisyonu üretemeyen GOÜ'lerde daha belirgin olmaktadır. Diğer yandan artan ithalat, gümrük görevlileri için rüşvet gelirinin marjinal faydasını artırmaktadır. Böylelikle ithalat artışından kaynaklanan rant arama faaliyetleri yolsuzluğu artırmaktadır. Daha fazla ithalat yapan küçük ülkelerin dışa açılmayla beraber piyasa mekanizmasında yönetişim faktörlerinin güçlenmesi beklenmektedir. Fakat rant faaliyetlerine yönelik motivasyonların azalmaması, ticari açıklıkla beraber yolsuzluğun artmasına yol açmaktadır. Tanzi (1998) ise uluslararası ticaretin ve ekonomik faaliyetlerin genişlemesinin, kârlı sözleşmelere erişim sağlayabilmek isteyen işletmelerin rüşvet faaliyetlerini artırdığını ileri sürmektedir. 


\section{Şekil 3. Ticari Açıklığın Yolsuzluğu Azaltma Mekanizmaları}

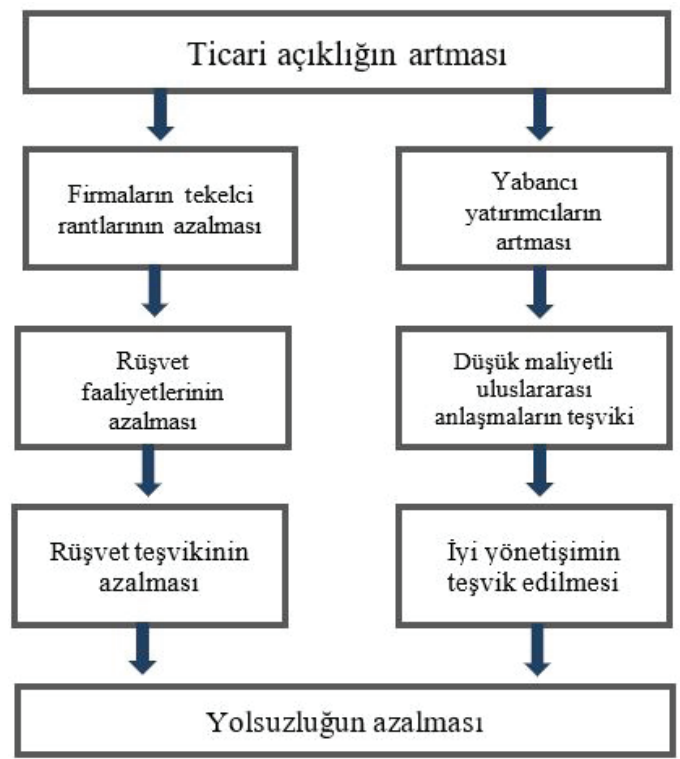

Kaynak: Majeed, 2014, s. 765.

Şekil 4. Dışa Açıklığın Yolsuzluğu Artırma Mekanizması

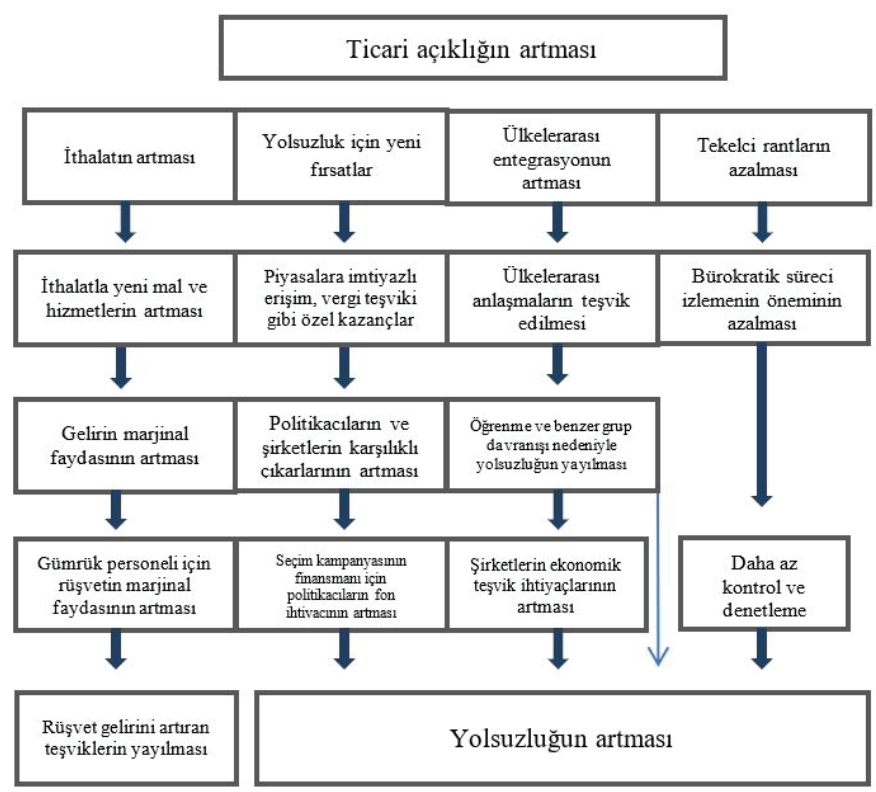

Kaynak: Majeed, 2014, s. 765. 
Ticari açıklı̆ın yolsuzluğu azaltma ve artırma mekanizmaları sırasıyla Şekil 3 ve Şekil 4'te gösterilmiştir. Şekil 3'te gösterilen yolsuzluğu azaltma mekanizmalarına göre ticari engellerin kaldırılmasıyla, tekelci rantlar ve rüşvet faaliyetleri azalmaktadır. Bunun yanında ticari açıklıkla birlikte uluslararası entegrasyonun artması, kurumsal yönetişimi güçlendirmektedir. Böylelikle ticari, açıklık yolsuzluğu azaltmaktadır. Şekil 4'te gösterilen işleyişe göre ticari açıklıkla beraber imtiyazlı kazançlar ve rüşvet motivasyonları artmaktadır. Ayrıca tekelci rantların azalması, bürokratik denetim mekanizmasını azaltarak daha az kontrole yol açmaktadır (Majeed, 2014).

Bonaglia, Macedo ve Bussolo (2001), ticaret engellerinin kaldırılmasının yolsuzluk üzerindeki etkisinin çok kısa vadede beklenilen yönde gerçekleşmeyeceğini vurgulamaktadır. Uzun dönemde, dış rekabetin getirdiği fırsatlardan daha fazla yararlanma imkânının artması ve kurumsal yapının değişmesiyle dışa açık ekonomilerde yolsuzluğun azalması beklenen durumdur. Kısa vadede ise ulusal politikalar, küreselleşmenin getirdiği avantajlar pahasına olabilmektedir. Bu durum, özellikle uluslararası entegrasyon ile eğitim, sağlık ve sosyal güvenlik gibi temel kalkınma projelerine yatırım yapmak arasında değiştokuş (trade-off) ile karşılaşmak zorunda kalan yoksul ülkeler için daha önemli olmaktadır.

\section{Literatür Özeti}

Ticari açıklığın, politik karar alma süreci ve kurumsal yapıyla yakından ilişkili olan yolsuzluk üzerindeki etkisini araştıran çalışmalar incelendiğinde sonuçların değiştiği görülmektedir. Sonuçların değişkenlik göstermesinin en önemli nedenlerinden birisi, ticari açıklık ve yolsuzluk göstergesi olarak farklı parametrelerin dikkate alınmasıdır. Dışa açıklık göstergesi olarak ithalatın ve ihracatın toplam değerinin GSYIH içerisindeki payı (\%) yanında, ithalatın GSYiH içerisindeki payı veya ekonomik küreselleşme endeksi yaygın olarak kullanılırken, yolsuzluk göstergesi olarak yolsuzluk kontrolü, yolsuzluk algılama endeksi ve şeffaflık endeksi kullanılmaktadır. Bahsedilen çalışmaların bazılarının ulaştığı sonuçlar aşağıda özetlenmektedir. 
Bonaglia ve ark. (2001), 119 ülkede 1984-88 ve 1990-98 dönemleri için ithalatın serbestleştirilmesinin, yönetişimin en önemli göstergelerinden birisi olan yolsuzluğu negatif etkilediği sonucuna ulaşmışlardır. Bu etkinin büyüklüğü de dikkate değerdir. İthalat serbestliğinin yolsuzluk üzerindeki etkisi kişi başı gelirin üçte birine eşit olmaktadır.

Torrez'in (2002) geniş ülke grubu için panel veri analizi tekniğiyle yaptığı çalışmanın sonuçları, genel itibarıyla ticari açıklık ile yolsuzluk arasındaki negatif ilişkiyi desteklemesine rağmen; bu sonuçlar tüm veri seti için geçerli değildir. Diğer bir ifadeyle ticari açıklk ile yolsuzluk arasındaki ilişki, yolsuzluk endeksinin seçimine bağlı olarak değişmektedir. ICRG (International Country Risk Guide) gibi geniş veri seti kullanıldığında bile dışa açıklık ile yolsuzluk arasındaki negatif yönlü ilişkiye dair zayı kanıtlar elde edilmektedir.

Knack ve Azfar'ın (2003) farklı dönemlere ait veri seti kullanarak ticari yoğunluk ile yolsuzluk arasındaki ilişkiyi ölçtükleri analizin bulguları, bu iki değişken arasındaki ilişkinin güçlü olmadığını ortaya koymaktadır.

Neeman, Paserman ve Simhon (2008), dışa açık ve kapalı ekonomilerde yolsuzluğun büyüme üzerindeki etkisini ele aldıkları çalışmada, açık ekonomilerde yolsuzluğun büyüme üzerinde güçlü olumsuz etkiye olduğu sonucuna ulaşırlarken, buna karşılık kapalı ekonomilerde yolsuzluğun büyüme üzerinde negatif etkiye sahip olduğuna dair herhangi bir kanit elde edememişlerdir.

Zakaria (2009), 1984-2007 dönemine ait verileri kullanarak Pakistan için yaptığı çalışmada, ticari açıklı̆ın yolsuzluğu negatif etkilediği bulgusuna ulaşmıştır.

Senderovic (2009), Avrupa ülkelerinde yolsuzluğun belirleyicilerini incelemiştir. Elde edilen bulgular, hem ticari engellerin ve hem de ticari açıklığın yolsuzluk üzerindeki etkisinin zayıf olduğunu ortaya koymakla birlikte, ticari açıklık ile yolsuzluk arasındaki ilişkinin daha zayıf olduğunu göstermektedir. Söz konusu ülkelerde yolsuzluğu etkileyen en önemli faktörler, ülkelerin kilisenin devletten ayrılma geleneğine sahip olup olmaması veya önceki dönemlerde merkezi 
planlamaya dayalı ekonomiye sahip olup olmamasıdır. Daha da önemlisi, çalışma bütün kamusal müdahalelerin yolsuzluğu artırmadığını ortaya koymuştur. Avrupa ülkelerinde yolsuzluk seviyesi üzerinde büyük bir etkiye sahip olan bir diğer unsur, ulusal rekabeti sınırlayan düzenlemelerdir.

Musila ve Sigué (2010), Afrika ülkeleri ve ticari ortaklarında 1998-2007 periyodu için yolsuzluk ile dışa açıklık ilişkisine yönelik ampirik analizlerinde, bu iki değişken arasında negatif yönlü ilişkinin varlığını tespit etmişlerdir. Diğer bir ifadeyle yolsuzluk, ticari açıklı̆ı negatif etkilemektedir.

Majeed (2014), 146 ülke için 1984-2007 dönemi verilerini kullanarak ticari açıklığın yolsuzluk üzerindeki etkisini araştırmıştır. Elde edilen bulgulara göre lineer modelde ticari açılık yolsuzluğu artırırken, lineer olmayan (non-linear) modelde yolsuzluğu azaltmaktadır. Dolayısıyla lineer ve lineer olmayan model sonuçları, ticari açıklık ile yolsuzluk arasındaki ilişkinin neden kesin olmadığını ortaya koymaktadır.

Marjit, Mandal ve Roy (2014), 98 ülke için 1982-1997 dönemine ait verilerle ticari açıklık ve yolsuzluk arasındaki ilişkiyi faktör yoğunluğu çerçevesine incelemiştir. Elde edilen ampirik sonuçlara göre yolsuzluk, emek-yoğun ve sermaye yoğun ülkelerde ticari açıklık üzerinde asimetrik bir etkiye sahiptir. Yolsuzluğun artması, düşük gelirli emek-yoğun ülkelerde ticari açılığı azaltırken; yüksek gelirli sermaye-yoğun ülkelerde ticari açıklığı artırmaktadır.

Gokcekus, Muchova ve Brincikova (2015), 1966-2009 yılları arası verilerle Avrupa ve Orta Asya (ECA) ülkelerinde ticari açıklığın seviyesinin ve kalitesinin yolsuzluk üzerindeki etkisini ele almışlardır. Analiz sonuçları, gerek ticari açıklığın gerekse de ticari açıklığın kalitesinin yolsuzluğu azalttığını göstermektedir. Elde edilen bulgular politika çıkarımları bağlamında ifade edilecek olursa; daha fazla ticari açıklık, daha fazla dış rekabet ve daha az yolsuzluk seviyesine sahip ülkelerle ticari faaliyetlerin geliştirilmesi, ECA ülkelerinde daha düşük yolsuzluğa yol açmaktadır. 
Gezikol ve Tunahan (2018), dışa açıklık, yolsuzluk ve doğrudan yabancı yatırımlar arasındaki ilişkiyi 1995-2015 (ICRG değişkeni kullanıldığında 124 ülke) ve 2003-2015 (CPI değişkeni kullanıldığında 122 ülke) dönemleri için araştırmışlardır. Farklı gelir grupları için yapılan tahmin sonuçlarına göre ICRG endeksinin dikkate alındığı modelde, düşük gelirli ülkelerde ihracat artışı yolsuzluğu artırmaktadır. Düşük-orta gelirli ülkelerde ithalat artışı yolsuzluğa neden olurken; yüksek-orta gelirli ülkelerde ihracattaki artış yolsuzluğu artırmaktadır. CPI endeksinin dikkate alındığı modelde, düşük-orta gelirli ülkelerde ithalatın artması yolsuzluğu azaltmaktadır. Yüksek-orta gelirli ülkelerde, ithalatın artması yolsuzluğu azaltırken; ihracatın artması yolsuzluğu arttırmaktadır.

Bu çalışmada verilerin erişilebilirliği kapsamında The Global Economy veri tabanından elde edilen yolsuzluk kontrol endeksi, yolsuzluk göstergesi olarak kullanılmıştır. 1996-2018 dönemi verileriyle bu gösterge kullanılarak seçilmiş MENA ülkeleri ile Türkiye için analiz edilmiştir. Yolsuzluğun ekonomik büyüme, refah, dış ticaret ve yabancı yatırım gibi makroekonomik büyüklükler üzerindeki ilişkisini inceleyen zengin bir literatür söz konusu olmakta birlikte, özellikle ticari açıklığın yolsuzluk üzerindeki etkisini araştıran çalışmaların çok sınırlı olduğu görülmektedir. Bunun yanında kurumsal faktörlerle ekonomik performans arasındaki ilişki gelişmekte olan ülkeler açısından daha önemli bir alandır. Ülke deneyimleri incelendiğinde kurumsal altyapının yeterli ölçüde gelişmediği ülkelerde dışa açıklığın yol açtığı kırılganlıklar ve istikrarsızıklar geniş kapsamlı etkilere yol açabilmektedir. Bu çerçevede MENA ülkeleri ve Türkiye'den oluşan ülke grubu için ticari açıklık ve yolsuzluk ilişkisinin incelenerek literatürdeki boşluğun doldurulması amaçlanmaktadır.

\section{Model, Veri ve Yöntem}

Çalışmada, 1996-2018 yılları için 14 MENA ülkesi (Cezayir, Bahreyn, Mısır, İran, İsrail, Ürdün, Kuveyt, Lübnan, Malta, Fas, Umman, Katar, Suudi Arabistan ve Tunus) ile Türkiye için yolsuzluk ile ticari açıklık, ekonomik büyüme, hukukun üstünlüğü ve kamu harcamaları arasındaki ilişkinin test edilmesi amaçlanmıştır. 
Torrez (2002), Zakaria (2009) ve Majeed'in (2014) çalışmasını takiben ampirik model aşağıdaki gibi kurulmuştur:

$$
\operatorname{COR}_{i t}=\delta_{0}+\delta_{1} \operatorname{LnGDP}_{i t}+\delta_{2} \text { LnTrade }_{i t}+\delta_{3} \text { Law }_{i t}+\delta_{4} \text { LnGovExp }_{i t}+\varepsilon_{i t}
$$

Ampirik analizde kullanılan değişkenlerin kapsamı ve bunların elde edildiği kaynaklar Tablo 1'de verilmektedir.

Tablo 1: Değişkenlerin Tanımları, Kapsamı ve Elde Edildiği Kaynaklar

\begin{tabular}{|l|l|l|}
\hline Değişken & Tanımları & Elde Edildiği Kaynak \\
\hline COR & $\begin{array}{l}\text { Yolsuzluğun kontrolünü ifade etmektedir. Endeks } \\
\text { değeri -2,5 ile 2,5 arasında değer almaktadır. } \\
-2,5 \text { yolsuzluğun kontrolünün zayıf; 2,5 ise güçlü } \\
\text { olduğunu ifade etmektedir. }\end{array}$ & The Global Economy \\
\hline GDP & $\begin{array}{l}\text { 2010 yılı sabit fiyatlarıyla kişi başı reel GSYiH } \\
\text { değerini ifade etmektedir. }\end{array}$ & World Bank \\
\hline Trade & $\begin{array}{l}\text { Mal ve hizmet ihracatı ile ithalatının toplam } \\
\text { değerinin GSYiH içerisindeki payını (\%) } \\
\text { göstermektedir. }\end{array}$ & World Bank \\
\hline Law & $\begin{array}{l}\text { Hukukun üstünlüğünü ifade etmektedir. Endeks } \\
\text { değeri -2,5 ile 2,5 arasında değer almaktadır.-2,5 } \\
\text { hukukun üstünlüğünün zayıf; 2,5 ise güçlü } \\
\text { olduğunu ifade etmektedir. }\end{array}$ & The Global Economy \\
\hline GovExp & $\begin{array}{l}\text { Kamu harcamalarının GSYiH içerisindeki payını (\%) } \\
\text { göstermektedir. }\end{array}$ & The Global Economy \\
\hline
\end{tabular}

Kaynak: Yazar tarafından oluşturulmuştur.

Ampirik analizlerde incelenen olgular arasındaki uzun dönemli ilişki ortaya konulurken, ilk aşamada ele alınan serilerin çeşitli açılardan (ekonomik, politik, sosyal, kültürel vb.) birbirlerine bağımlı olup olmadığının tespiti önemlidir. Bu amaçla analizin ilk aşamasında yatay kesit bağımlılığının sınanması amacıyla Breusch ve Pagan (1980) tarafından geliştirilen LM testi, Pesaran (2004) tarafından geliştirilen CD testi ve Pesaran, Ullah ve Yamagata (2008) tarafından sapması düzeltilen LMadj testi kullanılmıştır. Panel veri analizinde yatay kesit bağımlılığı araştırılırken, $\mathrm{T}>\mathrm{N}$ ( $\mathrm{T}$ zaman boyutunu, $\mathrm{N}$ ise yatay kesit boyutunu temsil etmektedir) olduğu durumda Breusch-Pagan (1980) Lagrange Multiplier (LM) testi; her ikisi de büyük olduğunda Pesaran (2004) Cross-Section Dependence (CD) testi kullanılabilmektedir. Bunun yanında LM testi, grup ortalaması sıfır ve 
bireysel ortalama sıfırdan farklı olduğunda sapmalı olmaktadır. Pesaran ve ark. (2008), test istatistiğine varyansı ve ortalamayı da ilave ederek, bu sapmayı ortadan kaldırmıştır (Göçer, Mercan ve Hotunluoğlu, 2012, s. 456). T>N durumunda kullanılabilen LM testi aşağıdaki eşitlik yardımıyla tahmin edilmektedir (Bayraç ve Doğan, 2018, s. 32):

$$
L M=T \sum_{i=1}^{N-1} \sum_{j=i+1}^{N}\left(\hat{p}_{i j}^{2}\right) \sim x^{2} \frac{N(N-1)}{2}
$$

Pesaran (2004) tarafından geliştirilen CD testi, aşağıda verilen (3) nolu denklem yardımıyla hesaplanmaktadır.

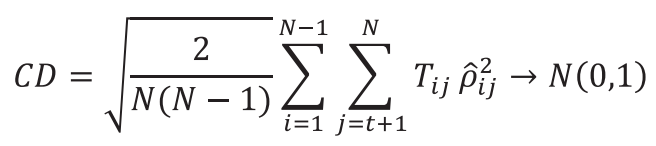

(3) nolu denklemde yer alan , kalıntılardan elde edilen korelasyon katsayılarını ifade etmektedir. T zaman boyutunu, $\mathrm{N}$ ise yatay kesit boyutunu ifade etmektedir. Denklemden elde edilen CD testinin temel hipotezleri şu şekildedir:

$\mathrm{H}_{0}$ : Yatay kesit bağımlılı̆̆ yoktur $\left(H_{0}: \hat{p}_{i j}=0 ; i \neq j\right)$

$H_{1}$ : Yatay kesit bağımlılı̆̆ vardır $\left(H_{1}: \hat{p}_{i j} \neq 0 ; i \neq j\right)$ şeklindedir (Nketia ve Kong, 2021, s. 28).

Sapması düzeltilmiş LM testi (LMadj) aşağıdaki test istatistiği yardımıyla hesaplanmaktadır (Pesaran ve ark., 2008, s. 108):

$$
L M_{a d j}=\sqrt{\frac{2}{N(N-1)}} \sum_{i=1}^{N-1} \sum_{j=i+1}^{N} \frac{(T-k) \hat{\rho}_{i j}^{2}-\mu_{T i j}}{v_{T i j}} \sim N(0,1)
$$

Bu testin hipotezleri de şu şekildedir:

$\mathrm{H}_{0}$ : Yatay kesit bağımlılığı yoktur.

$\mathrm{H}_{1}$ : Yatay kesit bağımlılığı vardır. 
Yatay kesit bağımlılığının sınanmasından sonra ikinci aşamada eğim katsayılarının homojen olup olmadığı araştırılmaktadır. Homojenlik testi için Swamy (1970) testinin geliştirilmiş versiyonunu ortaya koyan Pesaran ve Yamagata (2008) tarafından geliştirilen $\widetilde{\Delta}$ testi kullanılmaktadır.

$$
Y=\alpha+\beta_{i} X_{i t}+\varepsilon_{i t}
$$

Yukarıdaki (5) nolu eşitlikte yer alan, eğim katsayılarının yatay kesitler arasında homojen olup olmadığını test etmek için kullanılan bir parametredir. Testin hipotezleri şu şekilde ifade edilmektedir (Altıntaş ve Alancıoğlu, 2021, s. 270):

$H_{0}: \beta_{i}=\beta$ (Eğim katsayıları homojendir.)

$H_{0}: \beta_{i} \neq \beta$ (Eğim katsayıları homojen değildir)

Pesaran ve Yamagata (2008) testi, bir başka homojenite testi olan Swamy (1970) testinin geliştirilmiş versiyonu olmasından dolayı ilk olarak aşağıda yer alan Swamy (1970) testinin tahmin edilmesi gerekmektedir.

$$
\hat{S}=\sum_{i=1}^{N}\left(\hat{\beta}_{i}-\hat{\beta}_{W F E}\right)^{\prime} \frac{X_{i}^{\prime} M_{\tau} X_{i}}{\hat{\sigma}_{i}^{2}}\left(\hat{\beta}_{i}-\hat{\beta}_{W F E}\right)
$$

(6) nolu denklemde yer alan $\left.\hat{\sigma}_{i}^{2}, \hat{\sigma}_{i}^{2}=\frac{\left(y_{i}-X_{i} \hat{\beta}_{i}\right)^{\prime} M_{\tau}\left(y_{i}-X_{i} \widehat{\beta}_{i}\right)}{(T-k-1}\right), \widehat{\beta}_{i}$ iken havuzlanmış en küçük kareler sabit etkiler tahmincisi, $\hat{\beta}_{W F E}, \hat{\beta}_{W F E}=\left(\sum_{i=1}^{N} \frac{x_{i}^{\prime} M_{\tau} X_{i}}{\hat{\sigma}_{i}^{2}}\right)^{-1} \sum_{i=1}^{N} \frac{x_{i}^{\prime} M_{\tau} y_{i}}{\hat{\sigma}_{i}^{2}}$, olarak tanımlanan eğim katsayılarının ağırlıklandırılmış sabit etkiler havuzlanmış tahmincisini ifade etmektedir (Pesaran ve Yamagata, 2008, s. 54). $\widetilde{S}$, Swamy testi istatistiğini ifade etmek üzere, örneklem genişliğine göre $\widetilde{\Delta}$ testi aşağıdaki testler yardımıyla hesaplanmaktadır.

$$
\begin{aligned}
\widetilde{\Delta} & =\sqrt{N}\left(\frac{N^{-1} \tilde{S}-k}{\sqrt{2 k}}\right) \text { (büyük örneklem için } \widetilde{\Delta} \text { testi) } \\
\widetilde{\Delta}_{a d j} & =\sqrt{N}\left(\frac{N^{-1} \tilde{S}-E\left(\tilde{z}_{i T}\right)}{\sqrt{\operatorname{Var}\left(\tilde{z}_{i T}\right)}}\right) \text { (küçük örneklem için } \widetilde{\Delta} \text { testi) }
\end{aligned}
$$

(8) nolu eşitlikte $E\left(\tilde{z}_{i T}\right)=k$ ve $\operatorname{Var}\left(\tilde{z}_{i T}\right)=\frac{2 k(T-k-1)}{T+1}$ değerlerine eşittir (Pesaran ve Yamagata, 2008, s. 57). 
Eğim homojenitesinden sonra serilerin durağanlık sınamasında Pesaran (2007) tarafından geliştirilen tarafından ortaya atılan ve CADF (Cross-Sectional Augmented Dickey-Fuller) testinden türetilen CIPS birim kök testi kullanılmıştır. CADF, ADF modelinden türetilen bir testtir. $T>N$ ve $N>T$ şeklinde her iki durumda da kullanılabilen bu test, yatay kesit bağımlılığını dikkate almaktadır. CADF'nin regresyon modeli şu şekilde yazılmaktadır:

$$
\Delta y_{i t}=\alpha_{i}+b_{i} y_{i, t-1}+c_{i} \bar{y}_{t-1}+d_{i} \Delta y_{t}+e_{i t}
$$

(9) nolu eşitlikte yer alan $\bar{y}_{t-1}=N^{-1} \sum_{i=1}^{N} y_{i, t-1}$ ve $\Delta y_{t}=N^{-1} \sum_{i=1}^{N} \Delta y_{i t}$ iken, En Küçük Kareler (EKK) yöntemi ile her birim için tahmin edilen $b_{i}$ parametresinin $\mathrm{t}$ istatistikleri, her birime ait CADF istatistiğini vermektedir (Hashiguchi ve Hamori, 2010, s. 6).

$$
\operatorname{CIPS}(N, T)=N^{-1} \sum_{i=1}^{N} t_{i}(N, T)
$$

Yukarıdaki (10) nolu eşitlikteki CIPS testi, panel birim kök testi istatistiğini vermektedir.

Birim kök sınamasından sonra değişkenler arasındaki uzun dönemli ilişkinin tespit edilmesinde Eberhardt ve Bond (2009) tarafından geliştirilen AMG tahmincisi kullanılmıştır. AMG tahmincisinin en önemli avantajı, yatay kesit bağımlılığını ve eğim heterojenliğini dikkate almasıdır. Bu tahminci, gözlemlenemeyen ortak dinamik etkiyi tahmin etmek için iki aşamalı bir yöntem kullanmakta ve ortak dinamik etki katsayısını dâhil ederek yatay kesit bağımlılığına izin vermektedir (Atasoy, 2017, s. 737).

AMG tahmincisinin kullanılmasında iki aşama söz konusudur (Eberhardt ve Bond, 2009, s. 3):

I. Aşama

$\Delta y_{i t}=\mathrm{b}^{\prime} \Delta \mathrm{x}_{\mathrm{it}}+\sum_{\mathrm{t}=2}^{\mathrm{T}} \mathrm{c}_{\mathrm{t}} \Delta \mathrm{D}_{\mathrm{t}}+\mathrm{e}_{\mathrm{it}} \Rightarrow \hat{\mathrm{c}}_{\mathrm{t}} \equiv \hat{\mu}_{\mathrm{t}}$ 


\section{Aşama}

$$
y_{i t}=\alpha_{i}+b_{i}^{\prime} x_{i t}+c_{i} t+d_{i} \hat{\mu}_{\mathrm{t}}^{\cdot}+\mathrm{e}_{\mathrm{it}} \Rightarrow \hat{\mathrm{b}}_{\mathrm{AMG}} \sum_{\mathrm{i}=1}^{\mathrm{N}} \hat{\mathrm{b}}_{\mathrm{i}}
$$

(11) nolu denklemde yer alan $\Delta \mathrm{D}_{\mathrm{t}}$ zaman kuklalarını (dummy), zaman kuklalarının katsayısını ifade etmektedir. 1. aşamada (11) nolu denklemde birinci farkı alınmış EKK modeline (T-1) adet kukla (dummy) değişken eklenerek model tahmin edilmektedir. 2. Aşamada (12) nolu denklemin tahmin edilmesiyle elde edilen kukla parametreleri yatay kesit bağımlılığını içerek şekilde bağımsız değişken olarak kullanılmakta ve her yatay kesit için hesaplanan denklemlerin ortalaması AMG katsayısını vermektedir (Bayraç ve Doğan, 2018, s. 31).

Değişkenler arasındaki uzun dönemli ilişkinin tespit edilmesinden sonra bu defa değişkenler arasındaki nedensellik ilişkisinin tespit edilmesi amaçlanmıştır. Bu nedenle Dumitrescu-Hurlin (2012) testinden yararlanılmıştır.

$$
y_{i, t}=\alpha_{i}+\sum_{k=1}^{K} \gamma_{i}^{(k)} y_{i, t-k}+\sum_{k=1}^{K} \beta_{i}^{(k)} x_{i, t-k}+\varepsilon_{i, t}
$$

Dumitrescu-Hurlin nedensellik testinin regresyon modeli (13) nolu denklemdeki gibi kurulmaktadır. Denklemde $\beta_{i}=\left(\beta_{i}^{(1)}, \ldots \ldots, \beta_{i}^{(K)}\right)$ koşulları altında bireysel sabit etkileri, $\mathrm{K}$ paneldeki tüm yatay kesitler birimleri için aynı olduğunu ifade eden gecikme uzunluğunu, $\gamma_{i}^{(k)}$ gecikme parametrelerini ve $\beta_{i}^{(k)}$ eğim katsayısını göstermektedir (Dumitrescu ve Hurlin, 2012, s. 1451).

Dumitrescu-Hurlin nedensellik testinin temel hipotezleri ise aşağıdaki gibidir:

$H_{0}: \beta_{i}=0 \quad \forall_{i}=1, \ldots \ldots, N \quad$ (değişkenler arasında nedensellik ilişkisi yoktur)

$H_{1}: \beta_{i}=0 \quad \forall_{i}=1, \ldots \ldots, N_{1} \quad$ (değiş̧kenler arasında nedensellik ilişkisi vardır)

$\beta_{i} \neq 0 \quad \forall_{i}=N_{1}+1, N_{1}+2, \ldots, N$

\section{Ampirik Bulgular}

Analizin ilk aşamasında öncelikle modeli oluşturan seriler için Tablo 2'de yatay kesit bağımlılığı testi ve eğim homojenliği bulgularına yer verilmektedir. 
Tablo 2: Yatay Kesit Bağımlıı̆̆ı ve Homojenlik Test Bulguları

\begin{tabular}{|l|c|c|c|c|c|}
\hline & COR & LnGDP & LnTrade & Law & LnGovExp \\
\hline LM & $325.3^{* * *}$ & $321.6^{* * *}$ & $335.7^{* * *}$ & $307.2^{* * *}$ & $325.3^{* * *}$ \\
\hline LMadj & $38.84^{* * *}$ & $38.16^{* *}$ & $41.25^{* * *}$ & $36.19^{* * *}$ & $39.29^{* * *}$ \\
\hline CD & $32.586^{* * *}$ & $49.137^{* *}$ & $49.105^{* *}$ & $22.292^{* * *}$ & $49.024^{* * *}$ \\
\hline \multicolumn{2}{|l}{} & Test İstatistiği & Olasılık & \\
\hline \multirow{2}{*}{ Homojenlik Testi } & $\widetilde{\Delta}$ & 5.194 & 0.000 & \\
\cline { 2 - 6 } & & $\widetilde{\Delta}_{\text {adj }}$ & 6.042 & 0.000 & \\
\hline
\end{tabular}

Not: ${ }^{* \star \star}, \% 1$ düzeyinde anlamlılı̆ı ifade etmektedir.

Elde edilen bulgular incelendiğinde ilk olarak seriler arasında 'yatay kesit bağımlliğı yoktur' hipotezinin reddedildiği görülmektedir. Bu sonuç, ele alınan ülkelerden herhangi birisinde meydana gelecek olan şokun diğer ülkeleri de etkilediğini ifade etmektedir. Ülkeler arasında yatay kesit bağımllığının olması nedeniyle, yatay kesit bağımlılığını dikkate alan ikinci nesil birim kök testi kullanılmıştır. Bunun yanında yine Tablo 2'de homojenlik testi sonuçları için hesaplanan $\widetilde{\Delta}$ ve $\widetilde{\Delta}_{a j}$ istatistikleri, \%1 anlamlılık düzeyinde 'eğim katsayıları homojendir' şeklinde kurulan $\mathrm{H}_{0}$ hipotezinin reddedildiğini göstermektedir. Diğer ifadeyle eğim parametreleri yatay kesitler arasında değişmektedir.

Yatay kesit bağımlılığı ve eğim homojenliği sınamasından sonra yapılan serilerin durağanlık sınaması, Tablo 3'te yer almaktadır.

Tablo 3: Birim Kök Testi Bulguları

\begin{tabular}{|c|c|c|c|}
\hline \multicolumn{4}{|c|}{ CIPS Testi Sonuçları } \\
\hline Değişkenler & Düzey Değerleri & Fark Değerleri & Bulgu \\
\hline COR & $-3.297^{\star \star \star}$ & - & $I(0)$ \\
\hline LnGDP & -1.447 & $-3.368^{* \star *}$ & $\mathrm{I}(1)$ \\
\hline LnTrade & -1.508 & $-4.227^{* * *}$ & I(1) \\
\hline Law & $-3.584^{* \star *}$ & - & $I(0)$ \\
\hline LnGovExp & -1.821 & $-4.458^{\star \star \star}$ & $\mathrm{I}(1)$ \\
\hline
\end{tabular}

Not: ${ }^{* \star *}, \% 1$ düzeyinde anlamlılı̆ı ifade etmektedir.

CIPS birim kök testi sonuçlarının yer aldığı Tablo 3 incelendiğinde serilerin tamamının düzeyde durağan olmadığı görülmektedir. COR ve Law değişkenleri düzeyde durağanlık gösterirken, LnGDP, LnTrade ve LnGovExp değişkenleri birinci farkı alındığında durağan hâle gelmektedir. 
Önsel testlerden sonra değişkenler arasındaki uzun dönemli ilişkinin tespit edilmesi amacıyla kullanılan AMG testi bulguları Tablo 4'te sunulmaktadır.

Tablo 4: AMG Tahmincisi Bulguları

\begin{tabular}{|l|l|l|c|c|}
\hline & LnGDP & LnTrade & Law & LnGovExp \\
\hline Panel & $0.834^{\star *}$ & $-0.926^{\star}$ & $0.586^{* \star *}$ & $0.480^{* *}$ \\
\hline
\end{tabular}

Not: ${ }^{* * *,},+* *, \% 10, \% 5$ ve \%1 düzeyinde anlamlılığı ifade etmektedir.

Çalışmanın odak noktalarından birisini oluşturan uzun dönemli ilişkinin etkisine bakıldığında panel grubunu oluşturan ülkelerin geneli için LnGDP, Law ve LnGovExp değişkenlerinin COR değişkeni üzerinde pozitif; LnTrade ise negatif etkiye sahiptir. İktisadi açıdan yorumlandığında ekonomik büyümenin, hukukun üstünlüğünün ve kamu harcamalarının artması yolsuzluğun kontrolünü artırarak yolsuzluğu azaltmakta; buna karşılık küreselleşme çerçevesinde ticari açıklığın artması yolsuzluğun kontrolünü azaltarak, yolsuzluğu artırmaktadır. Elde edilen bulgular, değişkenler özelinde incelendiğinde politika yapıcılar için önemli sonuçlar ortaya koymaktadır. Illk olarak ekonomik büyümenin yolsuzluğun kontrolünü artırarak yolsuzluğu azaltması, çeşitli mekanizmalar aracılığıyla gerçekleşmektedir. İlk olarak, ekonomik büyümeyle birlikte yolsuzlukla mücadelede kullanılabilecek kaynaklar artmaktadır. Diğer taraftan ekonomik büyümeyle yolsuzluğun fırsat maliyeti yükseldiğinden yolsuzluk teşviklerinin azalmasına yol açmaktadır. Dolayısıyla ekonomik büyümenin yolsuzluğun kontrolünü artırması, sadece niceliksel olarak gelir artışı ve yaşam standardının iyileşmesine yol açmamakta, bunun yanında yolsuzluğu azaltarak kamusal malların kalitesini de iyileştirmektedir (Bhattacharyya ve Jha, 2013, s. 308). Çalışmanın temel çerçevesini oluşturan ticari açıklığın yolsuzluğun kontrolü üzerindeki negatif etkisi Bonaglia ve ark. (2001), Gezikol ve Tunahan (2018) gibi çalışmalarla tutarlıdır. Esasen ilgili literatür incelendiğinde ticari açıklığın ve daha geniş anlamda ele alındığında küreselleşme ile yolsuzluk ilişkisi çok net değildir. Fakat teorik ve ampirik literatürde ortaya konulduğu üzere, uluslararası piyasalarla bütünleşmenin daha düşük olduğu durumlarda yolsuzluk için daha düşük teşvikler söz konusu iken, ticari açıklıgın artmasıyla beraber yüksek seviyede yolsuzluk fırsatları ortaya çıkmaktadır. Dolayısıyla ekonomik entegrasyonun artmasıyla yolsuzluk uygulamalarını teşvik edecek durumların ortaya çıktığı, politika yapıcıların bu 
yolsuzluğu azaltacak kurumsal düzenlemeleri gerçekleştirmeleri gerekmektedir (Das ve DiRienzo, 2009, s. 42). Politika yapıcıların, dışa açıklıkla birlikte ortaya çıkan yolsuzluk teşviklerini azaltma noktasında uygulayabileceği en önemli politikaların başında, hukukun üstünlüğünün sağlanması gelmektedir. Ülkelerin ekonomik, politik ve sosyal alanlar üzerindeki etkisi tahmin edilenin çok ötesinde olan hukukun üstünlüğü (Mahmood, Tanveer, Ahmad ve Furqan, 2021), kurumsal kalitenin iyileştirilmesinde en önemli faktördür. Dolayısıyla hukukun üstünlüğünün inşa edildiği gelişmiş demokratik kurumsal yapı, yolsuzluğun azaltılmasında büyük etkiye sahiptir (Zakaria, 2009, s. 12). Benzer biçimde kamu harcamaları ile yolsuzluk arasındaki ilişkinin yönü de farklılaşmaktadır. Bu çalışmada kamu harcamalarının artmasının, yolsuzluğun kontrolü üzerindeki pozitif etkisi çeşitli görüşler çerçevesinde ortaya konulan yaklaşımlarla tutarlıdır. Genel itibarıyla yeni politik iktisat, kamu sektörünün büyümesiyle yolsuzluğun artacağına vurgu yapmaktadır (Rose-Ackerman, 1999; Alesina ve Angeletos, 2005). Buna karşılık, kamu harcamalarının artması veya kamu sektörünün genişlemesi; denge, denetleme ve hesap verilebilirliği güçlendirerek yolsuzluğu azaltmaktadır (Kotera, Okada ve Samreth, 2012, s. 2341).

Değişkenler arasındaki uzun dönemli ilişkinin tespitinden sonra nedensellik ilişkisi de önem kazanmaktadır. Tablo 5'te nedensellik bulgularına yer verilmektedir.

Tablo 5: Dumitrescu-Hurlin Nedensellik Testi Bulguları

\begin{tabular}{|l|c|c|c|}
\hline & W-stat. & Zbar-stat. & Olasıllk \\
\hline LnGDP $\neq$ COR & 2.21176 & 2.44737 & 0.0144 \\
\hline COR $\neq$ LnGDP & 2.59452 & 3.30353 & 0.0010 \\
\hline LnTrade $\neq$ COR & 2.68501 & 3.50594 & 0.0005 \\
\hline COR $\neq$ LnTrade & 0.37153 & -1.66893 & 0.0951 \\
\hline Law $\neq$ COR & 1.07157 & -0.10308 & 0.9179 \\
\hline COR $\neq$ Law & 1.70965 & 1.32422 & 0.1854 \\
\hline LnGovExp $\neq$ COR & 2.14115 & 2.28943 & 0.0221 \\
\hline COR $\neq$ LnGovExp & 0.85238 & -0.59337 & 0.5529 \\
\hline LnTrade $\neq$ LnGDP & 3.46669 & 5.25443 & 0.0007 \\
\hline LnGDP $\neq$ LnTrade & 2.52411 & 3.14605 & 0.0017 \\
\hline Law $\neq$ LnGDP & 2.79498 & 3.75193 & 0.0002 \\
\hline
\end{tabular}




\begin{tabular}{|l|l|l|l|}
\hline LnGDP $\neq$ Law & 3.78554 & 5.96765 & 0.0002 \\
\hline LnGovExp $\neq$ LnGDP & 2.43707 & 2.95134 & 0.0032 \\
\hline LnGDP $\neq$ LnGovExp & 1.80605 & 1.53985 & 0.1236 \\
\hline Law $\neq$ LnTrade & 1.61996 & 1.12359 & 0.2612 \\
\hline LnTrade $\neq$ Law & 3.04250 & 4.30560 & 0.0005 \\
\hline LnGovExp $\neq$ LnTrade & 2.26010 & 2.55548 & 0.0106 \\
\hline LnTrade $\neq$ LnGovExp & 1.16456 & 0.10494 & 0.9164 \\
\hline LnGovExp $\neq$ Law & 2.13645 & 2.27891 & 0.0227 \\
\hline Law $\neq$ LnGovExp & 2.03314 & 2.04781 & 0.0406 \\
\hline
\end{tabular}

Dumitrescu-Hurlin nedensellik testi bulguları incelendiğinde COR ile LnGDP, COR ile LnTrade, LnTrade ile LnGDP, Law ile LnGDP ve LnGovExp ile Law arasında çift yönlü nedensellik ilişkisi söz konusu iken; LnGovExp'ten sırasıyla COR'a, LnGDP'ye, LnTrade'e ve son olarak LnTrade'den Law'a doğru tek yönlü nedensellik ilişkisi söz konusudur.

\section{Sonuç ve Değerlendirme}

Küreselleşme ile birlikte dünya ekonomisinin entegrasyonu ciddi artış göstermiştir. 1970'te dünya mal ve hizmet ihracatının GSYIH içerisindeki payı \%13.3 iken, 2019 yılında iki katından fazla artarak \%29.5'e yükselmiştir. Benzer biçimde aynı dönem içerisinde ithalatın GSYIH içerisindeki payı \%13.3'ten \%28.7'ye yükselmiştir (World Bank, 2021). Mal ve hizmetlerin hareketliliğinin önündeki engellerin azaltılması ve sermaye piyasalarının serbestleştirilmesi, küreselleşmenin genişlemesinde önemli etkenler olmuştur. 1980'lerden itibaren özellikle az gelişmiş ve GOÜ'lerin ekonomilerini küresel ekonomiyle entegre etmeleri gerektiği ve bu yolla gelişmiş ülkeleri yakalayabilecekleri ileri sürülmüştür. Küreselleşmenin meydana getirdiği etkiler incelendiğinde bunların çok geniş kapsamlı oldukları görülmektedir. Dünya ekonomisinin birbirine giderek entegre olması, gerek ülke içinde gerekse de ülkeler arasında ekonomik ve politik açıdan birçok sonucu beraberinde getirmiştir. Dışa açıklığın yolsuzluk üzerinde meydana getirdiği etkiler bunlardan birisidir. Ülkelerin dışa açıklıkla birlikte elde ettiği fırsatlar, yolsuzluğun artması yönünde teşvikler sağlamaktadır. Özellikle GOÜ'lerin uluslararası piyasalarla daha fazla bütünleşme girişimi dikkate alındığında, dışa açıklık ve yolsuzluk ilişkisi bu ülkelerde daha önemli hâle gelmektedir. 
Bu çalışmada 14 MENA ülkesi (Cezayir, Bahreyn, Mısır, İran, İsrail, Ürdün, Kuveyt, Lübnan, Malta, Fas, Umman, Katar, Suudi Arabistan ve Tunus) ve Türkiye'den oluşan örneklem grubu için 1996-2018 dönemine ait veriler kullanılarak dışa açılık ile yolsuzluk arasındaki ilişki araştııılmışır. Değişkenler arasındaki uzun dönemli ilişkinin tespiti için Augmented Mean Group (AMG) tahmincisi kullanılmıştır. Elde edilen bulgulara göre dışa açıklık, yolsuzluğun kontrolünü negatif etkilemektedir. Bu sonuç, söz konusu ülkelerde ticari açıklığın yolsuzluğun kontrolünü zayıflatarak yolsuzluğu artırdığına yönelik bir çerçeve sunmaktadır. Kontrol değişkenleri olarak modele dâhil edilen ekonomik büyüme, hukukun üstünlüğü ve kamu harcamalarının yolsuzluğun kontrolü üzerindeki etkisi ise pozitif çıkmıştır. Uzun dönem katsayı tahmininden sonra değişkenler arasındaki nedensellik sonuçları, yolsuzluğun kontrolü ile ekonomik büyüme, yolsuzluk kontrolü ile ticari açılık, ticari açıklık ile ekonomik büyüme, hukukun üstünlüğü ile ekonomik büyüme ve kamu harcamaları ile hukukun üstünlüğü arasında iki yönlü ilişkinin varlığını ortaya koymaktadır. Buna ilave olarak nedensellik sonuçları kamu harcamalarından yolsuzluğun kontrolüne, ekonomik büyümeye ve ticari açıklığa; dışa açıklıktan hukukun üstünlüğüne doğru tek yönlü nedensellik ilişkisinin varlığını göstermektedir.

Incelenen ülke grubu ekonomik kazanımlar açısından son yıllarda önemli atılımlar gerçekleştirmiştir. Türkiye başta olmak üzere söz konusu ülkelerin büyük bölümü küresel ekonomide önemli yere sahiptir. Buna karşılık analiz edilen ülkelerin öne çıkan özelliklerinden birisi, gelişmiş ülkelerle kıyaslandığında kurumsal yönetişimin zayıf olmasıdır. The Global Economy (2021) verilerine göre 2020 yılında 192 ülke için yapılan hukukun üstünlüğü endeksi sıralamasında Cezayir 149. Bahreyn 59. Mısır 112. İran 152. İsrail 32. Ürdün 75. Kuveyt 66. Lübnan 154. Malta 37. Fas 91. Umman 50. Katar 33. Suudi Arabistan 73. Tunus 77. ve Türkiye 113. sırada yer almaktadır. Günümüz ekonomilerinde uluslararası ekonomide rekabetçi olabilmek için hukukun üstünlüğünün tesis edilmesi, hesap verilebilirlik ve şeffaflığın artırılması ve politik istikrarın sağlanması gibi yönetişim faktörleri giderek daha fazla önem kazanmaktadır. MENA ülkelerinin ve Türkiye'nin elde ettiği ekonomik kazanımların, politik süreçteki verimsizlik nedeniyle kaybolmaması adına kurumsal işleyişin güçlendirilmesi, politika yapıcıların üzerinde en fazla durması gereken hususlardan birisi olmalıdır. 
Hakem Değerlendirmesi: Dış bağımsız.

Çıkar Çatışması: Yazar çıkar çatışması bildirmemiștir.

Finansal Destek: Yazar bu çalışma için finansal destek almadığını beyan etmiştir.

Peer-review: Externally peer-reviewed.

Conflict of Interest: The author has no conflict of interest to declare.

Grant Support: The author declared that this study has received no financial support.

\section{Kaynaklar/References}

Alesina, A. \& Angeletos, G. M. (2005). Corruption, inequality, and fairness. Journal of Monetary Economics, 52(7), 1227-1244.

Altıntaş, H. ve Alancıoğlu, E. (2021). Dış borçlanma ve ekonomik büyüme: Gelişmekte olan ülkeler üzerine yatay kesit bağımlılığı altında panel veri analizi. Ömer Halisdemir Üniversitesi İktisadi ve Idari Bilimler Fakültesi Dergisi, 14(1), 261-279.

Atasoy, B. S. (2017). Testing the environmental Kuznets curve hypothesis across the U.S.: Evidence from panel mean group estimators. Renewable and Sustainable Energy Reviews, 77, 731-747.

Awokuse, T. O. (2008) Trade openness and economic growth: is growth export-led or import-led?. Applied Economics, 40(2), 161-173. DOI: 10.1080/00036840600749490.

Baksi, S., Bose, P., \& Pandey, M. (2009). The impact of liberalization on bureaucratic corruption. Journal of Economic Behavior \& Organization, 72(1), 214-224.

Barro, R. (1991). Economic growth in a cross section of countries. Quarterly Journal of Economics, $106,407-443$.

Bayraç, H. N. ve Doğan, E. (2018). Teknoloji yoksulluğu ve Türkiye'de ihracatın ithalata olan bağımlılığı. International Journal of Social Inquiry, 11(1), 17-42.

Bhattacharyya, S. \& Jha, R. (2013). Economic growth, law, and corruption: Evidence from India. Comparative Economic Studies, 55, 287-313. doi:10.1057/ces.2013.4.

Bonaglia, F., Macedo, J. B. D. \& Bussolo, M. (2001). How globalisation improves governance. OECD Working Paper No. 181, 1-40.

Breusch, T. S. \& Pagan, A. R. (1980). The lagrange multiplier test and its applications to model specification tests in econometrics. Review of Economic Studies, 47, 239-53.

Carvalho, M., Azevedo, A., \& Massuquetti, A. (2019). Emerging countries and the effects of the trade war between US and China. Economies, 7(45), 1-21. doi:10.3390/economies7020045.

Das, J. \& DiRienzo, C. (2009). The nonlinear impact of globalization on corruption. The International Journal of Business and Finance Research, 3(2), 33-46.

Deraniyagala, S. (2007). Uluslararası ticarette neoliberalizm: Sağlam bir iktisat kuramı mı, yoksa bir iman sorunu mu? Alfredo Saad-Filho ve Deborah Johnston (Haz.), Neoliberalizm: Muhalif bir seçki (2. Baskı, Şeyda Başlı \& Tuncel Öncel, Çev.), içinde (s. 168-178). İstanbul: Yordam Kitap.

Dumitrescu, E. I. \& Hurlin, C. (2012). Testing for Granger non-causality in heterogeneous panels. Economic Modelling, 29(4), 1450-1460. 
Eberhardt, M. \& Bond, S. (2009). Cross-section dependence in nonstationary panel models: a novel estimator. MPRA Paper No. 17692, 1-26.

Gezikol, B. ve Tunahan, H. (2018). The econometric analysis of the relationship between perceived corruption, foreign trade and foreign direct investment in the context of international indices. Alphanumeric Journal, 6(1), 117-132.

Gokcekus, O., Muchova, E., \& Brincikova, Z. (2015) Level and quality of openness and corruption in the ECA countries. Applied Economics Letters, 22(16), 1340-1344. DOI: 10.1080/13504851.2015.1031863.

Göçer, İ., Mercan, M., \& Hotunluoğlu, H. (2012). Seçilmiş OECD ülkelerinde cari işlemler açı̆ı̆ın sürdürülebilirliği: Yatay kesit bağımlılığı altında çoklu yapısal kıılmalı panel veri analizi. Maliye Dergisi, 163, 449-470.

Gygli, S., Haelg, F., Potrafke, N., \& Sturm, J. E. (2019). The KOF globalisation index-revisited. The Review of International Organizations, 14(3), 543-574.

Hashiguchi, Y. \& Hamori, S. (2010). Small sample properties of CIPS panel unit root test under conditional and unconditional heteroscedasticity. MPRA Paper No. 24053, 1-22.

Irwin, D. A. (2002). Did import substitution promote growth in the late nineteenth century. NBER Working Paper No.8751, 1-36.

Kay, C. (2011). Latin American theories of development and underdevelopment. London \& New York: Routledge.

Knack, S. \& Azfar, O. (2003). Trade intensity, country size and corruption. Economics of governance, 4(1), 1-18.

Kotera, G., Okada, K., \& Samreth, S. (2012). Government size, democracy, and corruption: An empirical investigation. Economic Modelling, 29(6), 2340-2348.

Krueger, A. O. (1974). The political economy of the rent-seeking society. The American Economic Review, 64(3), 291-303.

Mahmood, H., Tanveer, M., Ahmad, A. R., \& Furqan, M. (2021). Rule of law and control of corruption in managing $\mathrm{CO}_{2}$ emissions issue in Pakistan. MPRA Paper No. 109250, 1-15.

Majeed, M. T. (2014). Corruption and trade. Journal of Economic Integration, 29(4), 759-782. http:// dx.doi.org/10.11130/jei.2014.29.4.759.

Marjit, S., Mandal, B., \& Roy, S. (2014). Trade openness, corruption and factor abundance: Evidence from a dynamic panel. Review of Development Economics, 18(1), 45-58.

Musila,J. W. \& Yiheyis, Z. (2015). The impact of trade openness on growth: The case of Kenya. Journal of Policy Modeling, 37(2), 342-354.

Musila, J. W. \& Sigué, S. P. (2010). Corruption and international trade: an empirical investigation of African countries. World Economy, 33(1), 129-146.

Neeman, Z., Paserman, M. D., \& Simhon, A. (2008). Corruption and openness. The B.E. Journal of Economic Analysis \& Policy, 8(1), 1-38. https://doi.org/10.2202/1935-1682.2013.

Nketia, E. B. \& Kong, Y. (2021). Deciphering African financial development interaction with institutional quality and economic growth nexus. Etikonomi, 20(1), 24-44.

O'Rourke, K. H. (2000). Tariffs and growth in the late 19th century. Economic Journal, 110, 456-483. 
Pesaran, M. H. (2004). General diagnostic tests for cross section dependence in panels. CESifo Working Paper, No. 1229, Center for Economic Studies and ifo Institute (CESifo), Munich, 1-40.

Pesaran, M. H. (2007). A simple panel unit root test in the presence of cross-section dependence. Journal of Applied Econometrics, 22, 265-312.

Pesaran, M. H. \& Yamagata, T. (2008). Testing slope homogeneity in large panels. Journal of Econometrics, 142(1), 50-93.

Pesaran, M. H., Ullah, A., \& Yamagata, T. (2008). A bias-adjusted LM test of error cross-section independence. Econometrics Journal, 11, 105-127.

Rose-Ackerman, S. (1999). Corruption and government. Cambridge: Cambridge University Press.

Saad-Filho, A. (2005). The rise and decline of Latin American structuralism and dependency theory. In Jomo KS \& Erik S. Reinert (Eds.), The origins of development economics: How schools of economic thought have addressed development (pp. 128-145). New Delhi: Tulika Books.

Sachs, J. \& Warner, A. (1995). Economic reform and the process of global integration. Brookings Paper on Economic Activity, 1, 1-117.

Sarkar, P. (2008). Trade openness and growth: Is there any link?. Journal of Economic Issues, 42(3), 763-785. DOI: 10.1080/00213624.2008.11507178.

Senderovic, A. (2009). Trade restrictiveness or trade openness? The effects on corruption: A panel data study of the relation between trade restrictiveness and corruption in Europe in Jönköping University (Bachelor thesis). Retrieved from: https://www.diva-portal.org/smash/get/ diva2:228955/FULLTEXT01.pdfAuthor

Swamy, P. A. (1970). Efficient inference in a random coefficient regression model. Econometrica, 38(2), 311-323.

Tahir, M. \& Azid, T. (2015). The relationship between international trade openness and economic growth in the developing economies: Some new dimensions. Journal of Chinese Economic and Foreign Trade Studies, 8(2), 123-139.

Tanzi, V. (1998). Corruption around the world: Causes, consequences, scope, and cures. IMF Staff Papers, 45(4), 559-594.

The Global Economy (2021). Indicators. Retrieved from https://www.theglobaleconomy.com/ download-data.php Accessed 10.03.2020.

Torrez, J. (2002). The effect of openness on corruption. Journal of International Trade \& Economic Development, 11(4), 387-403.

Wei, S. J. (2001). Natural openness and good government. Center for International Development at Harvard University Working Paper No. 61, 1-30.

Williamson, J. (1990). What Washington means by policy reform. In John Williamson (Ed.), Latin American adjustment: How much has happened? (pp. 7-20). Washington, DC: Institute for International Economics.

World Bank (2021). World Bank open data. Retrieved from https://data.worldbank.org/ Accessed 14.03.2020.

Zakaria, M. (2009). Openness and corruption: A time-series analysis. Zagreb International Review of Economics \& Business, 12(2), 1-14. 
